\title{
FERMENTATION QUALITY OF KING GRASS SILAGE TREATED WITH LIQUID OR DRIED INOCULANT OF LACTIC ACID BACTERIA
}

\author{
B. Santoso ${ }^{\mathbf{1}}$, B. Tj. Hariadi ${ }^{\mathbf{1}}$ and $\mathbf{J e n i}^{\mathbf{2}}$ \\ ${ }^{1}$ Faculty of Animal Science, University of Papua, \\ Jl. Gunung Salju, Amban, Manokwari, Papua 98314 - Indonesia \\ ${ }^{2}$ Faculty of Mathematics and Natural Science, University of Papua, \\ Jl. Gunung Salju, Amban, Manokwari, Papua 98314 - Indonesia \\ Corresponding E-mail: santosob@lycos.com
}

Received September 29, 2015; Accepted November 11, 2015

\begin{abstract}
ABSTRAK
Tujuan penelitian ini adalah untuk mengevaluasi nilai nutrisi dan karakteristik fermentasi silase rumput raja yang diberi perlakuan penambahan inokulan cair atau kering bakteri asam laktat (BAL). Penelitian ini disusun dengan rancangan acak lengkap dengan 4 perlakuan dan 3 ulangan. Empat perlakuan yaitu (A) rumput raja tanpa inokulan BAL sebagai kontrol; (B) rumput raja $+30 \mathrm{~mL}$ inokulan cair BAL/kg hijauan segar; (C) rumput raja +30 g inokulan kering beku BAL/kg hijauan segar; (D) rumput raja $+30 \mathrm{~g}$ inokulan kering sentrifugasi BAL $/ \mathrm{kg}$ hijauan segar. Inokulan cair BAL disemprot pada permukaan rumput dan selanjutnya dicampur hingga rata. Konsentrasi awal BAL pada semua perlakuan adalah $1,0 \times 10^{6} \mathrm{cfu} / \mathrm{g}$. Sebanyak $500 \mathrm{~g}$ bahan silase diensilase dalam silo plastik dan disimpan pada temperatur ruang $\left(28^{\circ} \mathrm{C}\right)$ selama 30 hari. Hasil penelitian menunjukkan bahwa nilai $\mathrm{pH}$, konsentrasi asam laktat, $\mathrm{N}$-amonia $\left(\mathrm{N}-\mathrm{NH}_{3}\right)$, asam butirat, total volatile fatty acids (VFA) serta Nilai Fleigh dipengaruhi oleh perlahuan inokulan BAL. Silase yang diberi perlakuan inokulan cair atau kering BAL memiliki nilai $\mathrm{pH}$ lebih rendah $(\mathrm{P}<0,01)$ dibandingkan silase kontrol. Konsentrasi $\mathrm{N}_{-} \mathrm{NH}_{3}$ dan asam butirat signifikan lebih rendah $(\mathrm{P}<0,01)$ pada silase yang diberi perlakuan inokulan cair atau kering $\mathrm{BAL}$ dibandingkan silase kontrol. Silase yang diberi perlakuan inokulan BAL kering sentrifugasi memiliki Nilai Fleigh tertinggi $(\mathrm{P}<0,05)$ dibanding silase lain. Kecernaan neutral detergent fiber (NDF) in vitro lebih tinggi $(\mathrm{P}<0,05)$ pada silase yang diberi perlakuan inokulan BAL dibandingkan silase kontrol.
\end{abstract}

Kata kunci:bakteri asam laktat, fermentasi, inokulan, rumput, silase

\begin{abstract}
The aim of this study was to evaluate the nutritive value and fermentation characteristic of king grass silage treated with addition of liquid or dried lactic acid bacteria (LAB) inoculant. Experiment was arranged to a completely randomized design with four treatments and three replications. Four treatments as follows (A) king grass without LAB inoculant as the control; (B) king grass $+30 \mathrm{ml}$ of liquid of epiphytic LAB inoculant $/ \mathrm{kg}$ of fresh forage; (C) king grass $+30 \mathrm{~g}$ of freeze-dried powder of LAB inoculant $/ \mathrm{kg}$ of fresh forage; (D) king grass $+30 \mathrm{~g}$ of centrifuged powder of LAB inoculant $/ \mathrm{kg}$ of fresh forage. The liquid LAB inoculant was sprayed on the top of grass and then mannualy mixed by hand. The intial LAB concentration in all inoculants were $1.0 \times 10^{6} \mathrm{cfu} / \mathrm{g}$. About $500 \mathrm{~g}$ of silage materials were ensiled into plastic silos and stored at room temperatures (approximately $28^{\circ} \mathrm{C}$ ) for 30 days. Results showed that $\mathrm{pH}$ value, concentrations of lactic acid, $\mathrm{N}$-amonia $\left(\mathrm{NH}_{3}-\mathrm{N}\right)$, butyric acid and total volatile fatty acids (VFA) as well as Fleigh Point were affected by treatment of LAB inoculant. Silage treated with liquid or dried of LAB inoculant had lower $(\mathrm{P}<0.01) \mathrm{pH}$ value compared to the control silage. Concentrations of $\mathrm{NH}_{3}-\mathrm{N}$ and butyric acid significantly decreased $(\mathrm{P}<0.01)$ in silage treated with LAB
\end{abstract}


inoculants. Silage treated with centrifuged powder of LAB inoculant had the highest $(\mathrm{P}<0.05)$ Fleigh Point than other silage. In vitro neutral detergent fiber (NDF) digestibility was significantly higher $(\mathrm{P}<0.05)$ in silage treated with LAB inoculant compared to the control silage.

Keywords: fermentation, inoculant, grass, lactic acid bacteria, silage

\section{INTRODUCTION}

It is recognized that tropical grasses have low water soluble carbohydrate content, high buffering capacity and low lactic acid bacteria (LAB) number (Yahaya et al., 2004). These properties result in low lactic acid production; hence it is difficult to produce good-quality silage from tropical grasses. The epiphytic microorganisms existed naturally in forage crops are responsible for silage fermentation and also influence the effectiveness of silage bacterial inoculation. However, the number of LAB is usually low and vary depended on growing crops (McDonald, 1981).

The LAB plays an important role in silage fermentation and influence silage quality. Under natural circumstances, LAB grows as epiphytic bacteria, however, the population of $\mathrm{LAB}$ is usually low and variable with standing crops (Muck, 1990). Thus, addition of LAB inoculant is needed to improve silage quality (Bureenok et al., 2006). In the previous studies, Yahaya et al. (2004); Bureenok et al. (2006) stated that tropical and temperate forages ensiled with addition of epiphytic lactic acid bacteria inoculant resulting good fermentation quality compared to commercial inoculant. Santoso et al. (2009) concluded that fermentative quality of grass silage treated with epiphytic LAB prepared from king grass was better than those prepared from elephant grass. Similar result was reported in other experiment of Santoso et al. (2011); Santoso et al. (2012) that king grass and rice crop residue silages with addition of epiphytic LAB had good fermentation quality compared to control silage, as indicated by high lactic acid content and in vitro nutrient digestibility, and low ammonia-N $\left(\mathrm{NH}_{3}-\mathrm{N}\right)$ concentration. Wang et al. (2009) revealed that the effect of $\mathrm{LAB}$ from forage crop may be comparable or even better than commercial bacterial culture, because the commercial bacterial does not grow well on the target crop. Furthermore, addition of LAB inoculant in silage materials could improve fermentation quality of silage and nutrient digestibility. Whiter and Kung (2001) reported that microbial inoculant in a liquid-form was more effective than in a dry-form. Meanwhile, Kizilsimsek et al. (2007) stated that application of inoculant as a fresh culture in alfalfa silage resulted good fermentation profile than freezedried culture. Jeni et al. (2010) concluded method of drying by centrifugation produced higher bacteria viability than the method freezedrying. This experiment was carried out to evaluate the nutritive value and fermentation characteristic of king grass silage treated with addition of dried inoculant or liquid epiphytic LAB.

\section{MATERIALS AND METHODS}

\section{Forage Material}

King grass (Pennisetum purpureophoides) was planted in a $9 \mathrm{~m}^{2}$ plot without fertilizer at the experimental field of Faculty of Animal Science, University of Papua in Manokwari. Grass was harvested with a hand clipper after 50 days of regrowth defoliation. The experimental field is located at $134^{\circ} 04^{\prime}$ longitude and $00^{\circ} 48^{\prime}$ latitude. The area is located at an altitude of $110 \mathrm{~m}$ above sea level. The mean annual rainfall and temperature were $159.9 \mathrm{~mm}$ and $27.1{ }^{\circ} \mathrm{C}$, respectively.

\section{Preparation of Liquid and Dry Inoculants}

Preparation of liquid LAB inoculant according to modified of Bureenok et al. (2006) procedure as previously described by Santoso et al. (2009); Santoso et al. (2011); Santoso et al. (2012). The liquid inoculant was prepared using $220 \mathrm{~g}$ of fresh king grass, which was macerated in $1000 \mathrm{ml}$ of distilled water using a high-speed blender for $4 \mathrm{~min}$. The macerated material was filtered through two layers of cheese cloths, and $600 \mathrm{ml}$ of filtrate was collected in Erlenmeyer glass containing $18 \mathrm{~g}$ of glucose. The filtrate was mixed well and incubated anaerobically for $48 \mathrm{~h}$ at $30^{\circ} \mathrm{C}$. The number of $\mathrm{LAB}$ in the liquid or dried inoculants was counted before the experiments by using de Man, Rogosa, and Sharpe which were incubated for 3 days at $35^{\circ} \mathrm{C}$ (Bureenok et al., 2006).

Preparation of both freeze-dried powder and centrifuged powder of $\mathrm{LAB}$ inoculants according to modified method of Jeni et al. (2010). Briefly, 
1 liter of LAB culture was added to sterilized cassava powder and throughly mixed by hand. The mixed material was put on glass bottle and then dried by using freeze-dryer (Martin Christ 18436) for 36 hours. Furthermore, the freezedried powder of LAB was used as additive of king grass silage.

One liter of LAB culture was put in 4 glass bottle with capacity of $250 \mathrm{ml}$ and centrifuged at $10.000 \mathrm{rpm}$ for $5 \mathrm{~min}$. The supernantant was removed and remained about $10-15 \mathrm{ml}$ for each bottle. The remained supernatant was mixed with $250 \mathrm{~g}$ of sterilized cassava powder. Futhermore, the mixture LAB culture was used as additive of king grass silage.

\section{Silage Preparation and Treatments}

The fresh king grass was wilted at room temperature (approximately $28^{\circ} \mathrm{C}$ ) for $24 \mathrm{~h}$ and chopped into $3-5 \mathrm{~cm}$. The chopped grass was thoroughly mixed and a representative samples obtained. Total of 4 treatments were as follows (A) king grass without LAB as the control; (B) king grass $+30 \mathrm{ml}$ of liquid of epiphytic LAB inoculant/kg of fresh forage; (C) king grass $+30 \mathrm{~g}$ of freeze-dried powder of LAB inoculant $/ \mathrm{kg}$ of fresh forage; (D) king grass $+30 \mathrm{~g}$ of centrifuged powder of LAB inoculant $/ \mathrm{kg}$ of fresh forage. The intial $\mathrm{LAB}$ concentration in all inoculants were $1.0 \times 10^{6} \mathrm{cfu} / \mathrm{g}$. About $500 \mathrm{~g}$ of silage materials were packed into plastic silos and stored in the room temperature for 30 days. Each treatment was prepared in triplicate.

\section{Chemical Analyses}

Dried samples were used to determine dry matter (DM), ash and crude protein (CP) according to procedure of AOAC (2005). Procedure of Van Soest et al. (1991) was used to determined concentrations of neutral detergent fiber (NDF), acid detergent fiber (ADF) and acid detergent lignin (ADL). NDF was determined without the use of $\alpha$-amylase and sodium sulfite.

A $20 \mathrm{~g}$ of silage was macerated with $70 \mathrm{ml}$ of distilled water and stored at $4{ }^{\circ} \mathrm{C}$ for $24 \mathrm{~h}$. It was then homogenized for $15 \mathrm{~min}$ by using a shaker and filtered through a Whatman No. 1542 filter paper. The filtrate was used for determine of $\mathrm{pH}$, VFAs, lactic acid and $\mathrm{NH}_{3}-\mathrm{N}$. The $\mathrm{pH}$ value was determined using a $\mathrm{pH}$ meter (Hanna Hi 9025). Concentrations of individual VFAs were analyzed using a gas chromatography (Varian CP-9002 GC, Shimadzu, Japan) equipped with flame ionization detector (FID) and stainless steel column (1500 $\mathrm{mm} \times 3 \mathrm{~mm}$ i.d). The pressure of nitrogen was $1.25 \mathrm{~kg} / \mathrm{cm}^{2}$. The temperature of injector oven, column oven and detector were 220,130 and $220^{\circ} \mathrm{C}$, respectively. Concentrations of lactic acid and $\mathrm{NH}_{3}-\mathrm{N}$ were analyzed according to method of Barker and Summerson (1941); Chaney and Marbach (1962), respectively. Fleigh Point of the silage were calculated according to formulae as follows : Fleigh Point $=220+(2 \times \mathrm{DM} \%-15)$ $(40 \times \mathrm{pH})$, where Fleigh Point denote values between 85 and 100, very good quality; 60 and 80 , good quality; 55 and 60 , moderate quality; 25 and 40 , satisfying quality; $<20$ worthless (Ozturk et al., 2006).

\section{Statistical Analysis}

Data were subjected to analysis of variance for a completely randomized design. Duncan's multiple range test was used to separate treatment means, when probability was less than 0.05 .

\section{RESULTS AND DICUSSION}

\section{Chemical Composition of Silage}

The nutrients content of king grass silage treated with dry or liquid LAB inoculants are presented in Table 1. The DM content of silages was lower than the value of $30 \%$ for ideal silage as suggested by Chamberlain and Wilkinson (1996). Organic matter and crude protein contents in all silages were similar with the average values of $93.1 \%$ and $7.7 \%$, respectively. Organic matter content in this silage was slightly lower than value of $95.3 \%$ as reported by of Santoso et al. (2011). A slightly lower ADF content was observed in silage treated with $\mathrm{LAB}$ inoculants $(\mathrm{B}, \mathrm{C}$ and $\mathrm{D})$ than control silage. It has been reported that activity of cellulase and hemicellulase enzymes was high during ensilage (Yahaya et al., 2004). Similar results were also reported in previous findings using guinea grass and king grass silages (Ando et al., 2006; Santoso et al., 2009; Santoso et al., 2011).

\section{Characteristics Fermentation of Silage}

The final $\mathrm{pH}$ of silage treated with liquid and dry $\mathrm{LAB}$ inoculant was lower $(\mathrm{P}<0.01)$ than untreated silage (A) after 30 days of ensilaging (Table 2). Addition of lactic acid bacteria inoculants at ensiling ensured rapid and vigorous fermentation which resulted in faster accumulation of lactic acid. Furthermore, a high lactic acid concentration in those silages resulted in lower $\mathrm{pH}$ value. This result indicates that LAB 
Table 1. Chemical Composition (\%) of King Grass Silage Treated with Liquid or Dried Lactic Acid Bacteria Inoculants

\begin{tabular}{lrrrc}
\hline & \multicolumn{3}{c}{ Silages } \\
\cline { 2 - 5 } & \multicolumn{1}{c}{ A } & B & C & D \\
\hline Dry matter & 21.3 & 20.8 & 19.4 & 21.1 \\
Organic matter & 93.3 & 93.5 & 92.4 & 93.3 \\
Crude protein & 7.7 & 7.7 & 7.7 & 7.6 \\
NDF & 79.4 & 76.5 & 77.2 & 78.6 \\
ADF & 52.9 & 49.7 & 48.8 & 47.8 \\
Hemicelullose & 26.5 & 26.8 & 28.4 & 30.8 \\
\hline A: Silage witht
\end{tabular}

A: Silage without LAB inoculant; B: silage treated with liquid of epiphytic LAB inoculant; C: silage treated with freeze-dried powder of LAB inoculant; D: silage treated with centrifuged powder of LAB inoculant.

Table 2. Fermentation Characteristics of King Grass Silage Treated with Liquid or Dried Lactic Acid Bacteria Inoculants After 30 Days of Ensilage

\begin{tabular}{|c|c|c|c|c|c|c|}
\hline & \multicolumn{4}{|c|}{ Silages } & \multirow{2}{*}{ SEM } & \multirow{2}{*}{$P$} \\
\hline & $\mathrm{A}$ & $\mathrm{B}$ & $\mathrm{C}$ & $\mathrm{D}$ & & \\
\hline $\mathrm{pH}$ & $5.55^{\mathrm{A}}$ & $5.16^{\mathrm{B}}$ & $4.93^{\mathrm{B}}$ & $4.92^{\mathrm{B}}$ & 0.05 & 0.01 \\
\hline Lactic acid (g/kg DM) & $54.6^{\mathrm{B}}$ & $67.3^{\mathrm{A}}$ & $72.7^{\mathrm{A}}$ & $65.7^{\mathrm{AB}}$ & 2.51 & 0.01 \\
\hline $\mathrm{NH}_{3}-\mathrm{N}(\mathrm{g} / \mathrm{kg}$ total $\mathrm{N})$ & $89.7^{\mathrm{A}}$ & $46.6^{\mathrm{B}}$ & $45.0^{\mathrm{B}}$ & $39.4^{\mathrm{C}}$ & 4.40 & 0.01 \\
\hline Acetic acid (g/kg DM) & 11.3 & 10.0 & 7.8 & 10.0 & 0.75 & 0.06 \\
\hline Propionic acid (g/kg DM) & 3.7 & 3.0 & 2.2 & 2.1 & 0.78 & 0.45 \\
\hline Butyric acid (g/kg DM) & $8.0^{\mathrm{A}}$ & $4.9^{\mathrm{B}}$ & $7.5^{\mathrm{A}}$ & $1.8^{\mathrm{C}}$ & 0.43 & 0.01 \\
\hline Total VFA (g/kg DM) & $23.0^{\mathrm{a}}$ & $17.9^{\mathrm{b}}$ & $17.5^{\mathrm{b}}$ & $13.8^{\mathrm{b}}$ & 1.47 & 0.05 \\
\hline Fleigh Point & $18.6^{\mathrm{b}}$ & $37.5^{\mathrm{ab}}$ & $47.1^{\mathrm{ab}}$ & $50.2^{\mathrm{a}}$ & 5.59 & 0.02 \\
\hline
\end{tabular}

Means in the same row followed by different superscript are different $\left({ }^{\mathrm{a}-\mathrm{b}} \mathrm{P}<0.05 ;{ }^{\mathrm{A}-\mathrm{C}} \mathrm{P}<0.01\right)$.

produced high lactic acid concentration during incubation which resulted in low $\mathrm{pH}$ value. This result is consistent with previous studies by Santoso et al. (2009); Santoso et al. (2011) that $\mathrm{pH}$ value in king grass extract declined from average of 6.62 to 3.40 after $48 \mathrm{~h}$ of incubation at $30^{\circ} \mathrm{C}$. Trend declined $\mathrm{pH}$ value in extracts of grass and legume after $48 \mathrm{~h}$ of incubation have been also reported by Bureenok et al. (2006) and Wang et al. (2009). Similar to this findings, Kizilsimsek et al. (2007) reported that the addition of an inoculant in water was more effective than in a dry application of the same inoculant in grass silage. In the previous study, Whiter and Kung (2001) revealed that alfalfa silage with $30 \%$ DM treated with both dry and liquid of LAB inoculant had lower $(\mathrm{P}<0.05) \mathrm{pH}$ value than untreated silage at 2 days after ensiling.

Concentrations of lactic acid, $\mathrm{NH}_{3}-\mathrm{N}$, butyric acid, total VFA and Fleigh Point were affected $(\mathrm{P}<0.01)$ by $\mathrm{LAB}$ inoculants. Concentration of lactic acid in silages of $\mathrm{B}$ and $\mathrm{C}$ were significantly 
$(\mathrm{P}<0.01)$ higher as compared to control silage (A). This result agrees with previous study on silages prepared with tropical grasses as reported by Yahaya et al. (2004); Bureenok et al. (2006), and lucerne silage by Filya et al. (2007); Wang et al. (2009). Increased lactic acid concentration in silage treated with epiphytic LAB could be due to increasing fermentation process by LAB which converts monosaccharide such as glucose and fructose to lactic acid. However, concentration of lactic acid in king grass silages treated LAB were slightly lower than the ideal range of lactic acid concentration from 80 to $120 \mathrm{~g} / \mathrm{kg} \mathrm{DM}$ as recommended by Chamberlain and Wilkinson (1996).

Silages treated with $\mathrm{LAB}$ inoculants $(\mathrm{B}, \mathrm{C}$ and $\mathrm{D})$ had lower $(\mathrm{P}<0.01)$ concentration of $\mathrm{NH}_{3}$ $\mathrm{N}$ than control silage (A). This result was consistent with previous study of Santoso et al. (2011) who found that use of fermented forage extract increased lactic acid and greatly inhibited the clostridial activity to protect proteins from extensive degradation. Owens et al. (2002) revealed that during ensiling protein is degraded to peptides and free amino acids by plant proteases. In addition, degradation of amino acids to ammonia and non-protein nitrogenous fraction is predominantly due to proteolytic clostridia. Chamberlain and Wilkinson (1996) concluded that ammonia-N is as an indicator of the proportion of the total $\mathrm{N}$ which has been completely degraded during ensiling. Hence, concentration of ammonia- $\mathrm{N}$ is the best indicator of secondary fermentation. The growth of proteolytic clostridia, which degrade protein and amino acids to $\mathrm{NH}_{3}$, is inhibited by low $\mathrm{pH}$ (McDonald, 1981; Winters et al., 2000). This result was supported by the low $\mathrm{pH}$ values in silage $\mathrm{B}, \mathrm{C}$ and $\mathrm{D}$ compared to silage $\mathrm{A}$. This condition could depress the growth of proteolytic clostridia. The target value for $\mathrm{NH}_{3}-\mathrm{N}$ in silage is less than $50 \mathrm{~g} / \mathrm{kg}$ total $\mathrm{N}$ (Chamberlain and Wilkinson, 1996). Based on $\mathrm{NH}_{3}-\mathrm{N}$ concentration in the Table 3, silage $\mathrm{B}, \mathrm{C}$ and $\mathrm{D}$ could be classified in normal range of $\mathrm{NH}_{3}-\mathrm{N}$ concentration.

Concentration of butyric acid was lower $(\mathrm{P}<0.01)$ in silage $\mathrm{B}$ and $\mathrm{D}$ compared to control silage (A). The result indicates that clostridia bacteria was more active in control silage (A) than silage treated with liquid epiphytic $\mathrm{LAB}$ or centrifuged powder of LAB inoculant. According to Chamberlain and Wilkinson (1996), secondary fermentation occurs insufficient acid is produced by the primary fermentation to reduce the $\mathrm{pH}$ to below a critical level of about 4.5. The bacteria responsible for secondary fermentations are mainly the clostridia. These bacteria may convert lactic acid to butyric, or may degrade proteins, peptides and amino acids to amines and ammonia. McDonald et al. (1987) also reported that butyric acid is produced by saccharolytic clostridia i.e. Clostridium butyricum. The total VFA concentration was slightly lower in silages treated with LAB inoculant than control silage. The result indicates that addition of $\mathrm{LAB}$ inoculant to king grass could improve fermentative quality of silage. Chamberlain and Wilkinson (1996) stated that the VFA comprise acetic acid, propionic acid, butyric acid and other acids. The production of these acids is reflection of an inefficient fermentation or of secondary fermentation of lactic acid to butyric acid and degradation of amino acids to ammonia with the production of amino acid from skeleton of the amino acid. In the present study, the proportion of VFA to total acid

Table 3. In vitro Nutrient Digestibilities of King Grass Silage Treated with Liquid or Dried LAB Inoculants

\begin{tabular}{lcccccc}
\hline & \multicolumn{9}{c}{ Silage } & & \\
\cline { 2 - 5 } & A & B & C & D & SEM & $P$ \\
\hline Dry matter & 47.9 & 52.7 & 49.1 & 49.0 & 1.91 & 0.43 \\
Organic matter & 48.0 & 54.3 & 51.4 & 51.1 & 1.22 & 0.29 \\
NDF & $19.0^{\mathrm{b}}$ & $28.2^{\mathrm{a}}$ & $27.0^{\mathrm{a}}$ & $27.2^{\mathrm{a}}$ & 1.37 & 0.03 \\
\hline
\end{tabular}

Means in the same row followed by different superscripts are significantly different $\left({ }^{\mathrm{a}-\mathrm{b}} \mathrm{P}<0.05\right)$. 
was 29.6, 21.0, 19.4 and $17.4 \%$, respectively for silage A, B, C and D. The result indicates that fermentation of silage $D$ was more efficient than silage A, B and C. However, the values found in silage A and B are still above than ideal value of $20 \%$ as recommended by Chamberlain and Wilkinson (1996).

Silage D had the highest $(\mathrm{P}<0.05)$ Fleigh Point than other silages, suggesting that silage treated with centrifuged powder of LAB inoculant at level of $3 \%(\mathrm{v} / \mathrm{w})$ had better fermentative quality as compared to other silages. In addition, Fleigh point found in the present study was lower than the value of 72.83 in alfalfa-maize silage mixture and 62.3 in rice crop residue-based silage as reported by Ozturk et al. (2006) and Santoso et al. (2012), respectively.

\section{In vitro Nutrient Digestibilities}

Table 3 depicts the result of in vitro DM, $\mathrm{OM}$ and NDF digestibilities of king grass silage treated with liquid and dried LAB inoculants. Treatments of LAB inoculants had no effect on IVDMD and IVOMD values $(\mathrm{P}>0.05)$. This result was inconsistant with previous finding of Ando et al. (2006) that addition of LAB increased the digestibility of $\mathrm{DM}, \mathrm{OM}$, and $\mathrm{CP}$ of guinea grass silage. On the other hand, IVNDFD of king grass silage was affected by addition of LAB inoculant $(\mathrm{P}<0.05)$. The IVNDFD increased by average of $44.6 \%$ when liquid or dried LAB inoculants was added. Increasing IVNDFD in silages with addition of $\mathrm{LAB}$ inoculant $(\mathrm{B}, \mathrm{C}$ and $\mathrm{D})$ in the present study could be due to lower NDF and ADF contents. It has been reported that activity of cellulase and hemicellulase enzymes was high during ensilage (Yahaya et al., 2004). ). In other study, Nsereko et al. (2008) concluded that some LAB produced ferulate esterase that can increase susceptibility of plant cell walls to enzymatic hydrolysis. Similar results were also reported in other experiments using guinea grass and king grass silages (Ando et al., 2006; Santoso et al., 2009; Santoso et al., 2011).

\section{CONCLUSION}

Application of the LAB inoculant as a dry formulation with centrifugation method resulted in faster decline silage $\mathrm{pH}$, decreased $\mathrm{NH}_{3}-\mathrm{N}$ and butyric acid concentration and increased Fleigh Point than when the inoculant was applied as a liquid formulation.

\section{ACKNOWLEDGMENT}

This research was funded by the Indonesian Ministry of Education and Culture through Hibah Bersaing Program (Contract No. 286c/UN42/2013).

\section{REFERENCES}

Ando, S., M. Ishida, S. Oshio and O. Tanaka. 2006. Effects of isolated and commercial lactic acid bacteria on the silage quality, digestibility, voluntary intake and ruminal fluid haracteristics. Asian-Aust. J. Anim. Sci. 19: 386-389.

AOAC (Association of Official Analytical Chemists). 2005. Official Methods of Analysis. $17^{\text {th }}$ Ed. Washington: AOAC International.

Barker, S. B. and W.H. Summerson. 1941. The colorimetric determination of lactic acid in biology material. J. Biol. Chem. 138:535554.

Bureenok, S., T. Namihira, S. Mizumachi, Y. Kawamoto and T. Nakada. 2006. The effect of epiphytic lactic acid bacteria with or without different byproduct from defatted rice bran and green tea waste on napiergrass (Pennisetum purpureum Shumach) silage fermentation. J. Sci. Food Agric. 86:10731077.

Chamberlain, A.T. and J.M. Wilkinson. 1996. Feeding the Dairy Cow. Chalcombe Publications, Lincoln, UK.

Chaney, A.L. and E.P. Marbach. 1962. Modified reagents for determination of urea and ammonia. Clin Chem 8:130-132.

Filya, I, R. E. Muck and F. E. Contreras-Govea. 2007. Inoculant effects on alfalfa silage: fermentation products and nutritive value. J. Dairy Sci. 90:5108-5114.

Jeni, Hamim, A. Tjahjoleksono, dan I.D. Soemantri. 2010. Viabilitas dan efektivitas pupuk hayati dari beberapa teknik pengeringan dan lama penyimpanan. In: Supena Eds. Prosiding Seminar Nasional Sains III, FMIPA IPB Bogor, 13 November 2010. P. 50-60

Kizilsimsek, M., R. J. Schmidt and L. Kung Jr. 2007. Effects of a mixture of lactic Acid bacteria applied as a freeze-dried or fresh culture on the fermentation of alfalfa silage. J. Dairy Sci. 90:5698-5705.

McDonald, P. 1981. The Biochemistry of Silage. 
John Wiley \& Sons, Ltd. New York.

McDonald, P., R. A. Edwards, and J. F. D. Greenhalgh. 1987. Animal Nutrition. 4th edition. Longman Group Ltd. Hongkong.

Muck, R. E. 1990. Prediction of lactic acid bacteria numbers on lucerne. Grass Forage Sci. 45:273-280.

Nsereko, V.L., B. K. Smiley, W. M. Rutherford, A. Spielbauer, K. J. Forrester, G. H. Hettinger, E. K. Harman and B. R. Harman. 2008. Influence of inoculating forage with lactic acid bacteria strains that produce ferulate esterase on ensilage and ruminal degradation of fiber. Anim. Feed Sci. Technol. 145:122-135.

Ozturk, D., M. Kizilsimsek, A. Kamalak, O. Canbolat and C. O. Ozkan. 2006. Effects of ensiling alfalfa with whole-crop maize on the chemical composition and nutritive value of silage mixtures. Asian-Aust. J. Anim. Sci.. 19:526-532.

Owens, V. N., K. A. Albrecht and R. E. Muck. 2002. Protein degradation and fermentation characteristics of unwilted red clover and alfalfa silage harvested at various times during the day. Grass Forage Sci. 57:329341.

Santoso, B., B. Tj. Hariadi, H. Manik dan H. Abubakar. 2009. Kualitas rumput unggul tropika hasil ensilase dengan aditif bakteri asam laktat dari ekstrak rumput terfermentasi. Med. Pet. 32(2):138-145.

Santoso, B., B. Tj. Hariadi, H. Manik and H. Abubakar. 2011. Silage quality of king grass (Pennisetum purpureophoides) treated with epiphytic lactic acid bacteria and tannin of acacia. Med. Pet. 34(2): 140-145.

Santoso, B. B. Tj. Hariadi, Alimuddin and D. Y. Seseray. 2012. Fermentation characteristics of rice crop residue-based silage treated by epiphytic and commercial LAB. Med. Pet 35(1):60-66.

Van Soest, P. J., J. B. Robertson and B. A. Lewis. 1991. Methods for dietary fiber, neutral detergent fiber, and nonstarch polysaccharides in relation to animal nutrition. J. Dairy Sci. 74: 3583-3597.

Wang, J., J. Q. Wang, H. Zhou and T. Feng. 2009. Effects of addition of previously fermented juice prepared from alfalfa on fermentation quality and protein degradation of alfalfa silage. Anim. Feed Sci. Technol. 151:280290.

Winters, A. L., J. E. Cockburn, M. S. Dhanoa and R. J. Merry. 2000. Effects of lactic acid bacteria in inoculants on changes in amino acid composition during ensilage of sterile and nonsterile ryegrass. J. Appl. Microbiol. 89: 442-451.

Whiter A. G. and L. Jr. Kung. 2001. The Effect of a Dry or Liquid Application of Lactobacillus plantarum MTD1 on the Fermentation of Alfalfa Silage. J. Dairy Sci. 84:2195-2202.

Yahaya, M. S., M. Goto, W. Yimiti, B. Smerjai and Y. Kuwamoto. 2004. Evaluation of fermentation quality of a tropical and temperate forage crops ensiled with additives of fermented juice of epiphytic lactic acid bacteria (FJLB). Asian-Aust. J. Anim. Sci. 17: 942-946. 